\title{
Biological Characterization of Nepalese Soils
}

\section{Rajendra Prasad Uprety ${ }^{1 *}$ and Graeme I Paton ${ }^{2}$}

${ }^{1}$ School of Biological Science, University of Aberdeen, Scotland UK

${ }^{2} \mathrm{Head}$ of School, School of Biological Science, University of Aberdeen, Scotland UK

*Corresponding Author: Rajendra Prasad Uprety, Research student, School of Biological Science, University of Aberdeen, Scotland UK.

Received: September 25, 2018; Published: November 22, 2018

\begin{abstract}
Pedologists have given little attention to biological parameters in the classification of soils. Similarly, most soil biologists refer to soil on the basis of soil texture or site with no regard for international soil terminology. While it is considered that the relationship between soil microbial population, communities, and activities govern soil formation no biological characteristics have been used in soil taxonomic system as a diagnostic tool to classify soil. The aim of this study was to integrate biopedological characteristics that could distinguish between soil reference groups (Luvisols, Cambisols, Fluvisols and Regosols) within the WRB (world reference based) system with reference to Nepalese soil. The relationship between biological and chemical parameters was a clear way to discriminate between soils. The result supports the need to integrate soil biological parameters with soil reference groups. The influence of biological parameters such as DH (dehydrogenase), soil ATP (adenosine triphosphate) and phosphatase was observed in Regosols. Micc (microbial biomass carbon), and soil respiration were apparent in Cambisol (Panchkhal) and Fluvisols. However, the influence of PNR (potential nitrification rate), Soil ATP and phosphatase activities was observed in Cambisols (Batase). The influence of soil respiration, DH, micc, phosphatase and PNR was observed in Luvisols. The soil biological parameters complimented chemical and physical parameters used to characterise soils within WRB system. A very useful map could be developed for pedologists and biologists with regard to future soil uses.
\end{abstract}

Keywords: Biopedology; Microbial; Physiochemical; Cambisols; Regosols; Fluvisols; Lithosols

\section{Introduction}

Agriculture is the largest sector of Nepal's economy. The contribution of agriculture to GDP is $37 \%$. Crop production provides the largest component of agricultural GDP (about 61\%). Acid soils cover approximately $49 \%$ of the total geographical area in Nepal [25]. One of the major contributing factors for declining soil fertility in Nepal is soil acidification [32] resulting in an overall decline in productivity of the farming system. The impact of acidification has both direct and indirect consequences, and these have received the attraction of numerous studies. Data from long--term fertility treatment (N, P, K and FYM) were used to evaluate cropping intensity and soil fertility status in Terai region of Nepal. Yields were found to be higher in FYM, N, P, and K treatments than in the treatments where one or more nutrient was missing. The recommended dose of NPK used were 100, 17.5 and $25 \mathrm{~kg} \mathrm{ha}^{-1}$ for wheat and 100,
13 and $25 \mathrm{~kg} \mathrm{ha}^{-1}$ for rice crops [9]. Regmi., et al. [22] reported that adjustable fertilizers management strategy must ensure high and stable overall productivity and sufficient nutrient supply for potential increase in yields. Long-term fertility experiment data [22] suggested that depletion of soil $\mathrm{K}$ and unsatisfactory $\mathrm{K}$ application seemed to be major reason for declining crop yields. There has been no consideration of microbial aspects in the Nepalese context to enhance soil fertility. If a suitable audit of such properties where conducted it could be possible to prioritise soils that could be more effectively managed and that could be self-sustaining.

Very few studies regarding microbial activities in Nepalese soils have been carried out. Most studies concluded that the deficiency of nitrogen $(\mathrm{N})$ in the soil due to the volatilization, denitrification and leaching and potassium $(\mathrm{K})$ by leaching loss. Nitrogen and $\mathrm{K}$ depletion may have collectively contributed to the yield decline [3]. 
Powlsen., et al. [21] reported that change in soil organic matter affected soil microbial biomass and soil basal respiration found greater in high Ctot and Ntot content soils. Traove., et al. [32] further suggested that soil respiration is determined by substrate availability rather than size of microbial biomass under favourable temperature and moisture condition.

Soil types and sampling locations in Nepal [18]

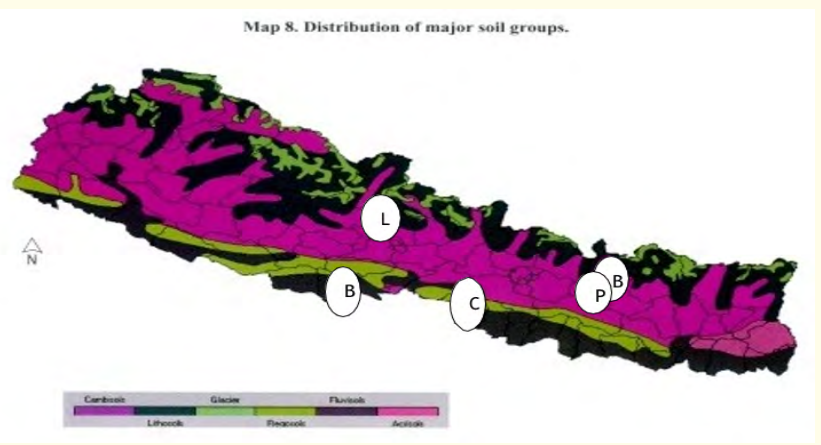

Figure

Based on WRB system, very few soil reference groups are found in Nepal. The soils are generally classified as Luvisols, which are shallow, and rocky soils found in the high hills of Nepal. Cambisols are most common and found in mid hills of Nepal. Regosols (high sand content) and Fluvisols (limited sand content) are also found in Nepal. Soil texture is described on the basis of soil colour notation. It was found to be clay loam, sandy loam and silty loam soils in hilly region [18].

\begin{tabular}{|c|c|c|}
\hline Soil types & Advantage & Disadvantage \\
\hline Black clay & $\begin{array}{c}\text { High Productivity } \\
\text { (Good for rice) }\end{array}$ & $\begin{array}{c}\text { Difficult to plough } \\
\text { Yield declines if rain fall } \\
\text { id high }\end{array}$ \\
\hline Red clay & Medium Productivity & $\begin{array}{c}\text { Difficult to plough } \\
\text { Yield declines if rain fall } \\
\text { id high }\end{array}$ \\
\hline $\begin{array}{c}\text { Brown/grey } \\
\text { loam }\end{array}$ & $\begin{array}{c}\text { High productivity in } \\
\text { normal years }\end{array}$ & $\begin{array}{c}\text { Yield declines if rainfall } \\
\text { is low }\end{array}$ \\
\hline $\begin{array}{c}\text { Sandy loam } \\
\text { Easy to plough }\end{array}$ & $\begin{array}{c}\text { Low Productivity } \\
\text { Yield declines substan- } \\
\text { tially if rainfall is low }\end{array}$ \\
\hline
\end{tabular}

Table 1: Generic comments about Nepalese soils [18].
Most soil biologists refer to soil by texture or site with no regards for international soil terminology. While pedologists describe the full profile of soil, biologists focus on the upper horizons. Pedologists consider the details of particle size analysis (PSA), extractable fraction and mineral transformation but soil biologists measure different chemical parameters like bioavailability, redox and gas flux. Both groups acknowledge that the other exists but the disciplines of soil classification and soil biology often have little interaction. Minashy., et al. [15] highlighted the significance of biomass in any pedogenic model. However, neither USDA soil taxonomy [26] nor World Reference Base (WRB) [10] include any measured soil biological parameters to distinguish characteristics to classify soils. Schipper and Sparling [24] tinted the value of a wide range of soil parameters including microbial measurement in the assessment of soil condition indicators across a range of land use and soil types. The difference in biological measurements reflected deterioration and vulnerability hence they were more temporary [12]. Xu., et al. [37] pointed out the relationship between soil microbial, chemical and physical characteristics in light of soil classification.

Therefore, this study was focused for better understanding of soil on key biological parameters as total soil microbial biomass Carbon, dehydrogenase activities, phosphatase activities, soil respiration, soil ATP, potential nitrification rate (PNR) and ammonical nitrogen (NH4+-N) and nitrate nitrogen (NO3--N) dynamics in this project regarding arable soils of developing countries for different topography, vegetation, climate and cropping system.

The aim of the study was to integrate biological and chemical parameters that could distinguish between different soils taxonomic groups found in Nepal (Luvisols, Cambisols, Fluvisols and Regosols) and to assess the strength of this relationship. Five different locations were selected and sampled on the basis of altitude, soil colour and soil texture. Relationship between biological and chemical parameters was studied to derive a comprehensive knowledge of interaction of these parameters.

\section{Materials and Method}

Site selection

Five different locations ranging from terai to mountain with different soil texture, soil colour and climate were selected. Each location has been classified into Low land (Khet) that is productive with good irrigation, and Up land (Bari), which is less productive, depend on rain fed irrigation. Two samples from each (Khet and Bari) have been collected. Twenty samples were collected in total from five different places. Brief soil sampling site description is given below. 


\begin{tabular}{|c|c|c|c|c|}
\hline Location & Altitude & Climate & Soil depth & Cropping Patterns \\
\hline $\begin{array}{c}\text { Bhairawa } \\
\text { (Fluvisoll) }\end{array}$ & $120 \mathrm{~m} \mathrm{(msl)}$ & Sub-tropical & $0-20 \mathrm{~cm}$ & $\begin{array}{c}\text { Rice-rice, Rice-Wheat, Maize-Rice, Rice-Vegetable, Maize- } \\
\text { Wheat, Maize- Mustard }\end{array}$ \\
\hline $\begin{array}{c}\text { Chitwan } \\
\text { (Regosol) }\end{array}$ & $224 \mathrm{~m} \mathrm{(msl)}$ & Sub-tropical & $0-20 \mathrm{~cm}$ & $\begin{array}{r}\text { Rice-Rice, Rice-Wheat, Maize-Rice, Rice-Vegetable, Maize- } \\
\text { Wheat, Maize-Mustard }\end{array}$ \\
\hline $\begin{array}{c}\text { Panchkhal } \\
\text { (Cambisol) }\end{array}$ & $750 \mathrm{~m} \mathrm{(msl)}$ & Sub-tropical & $0-20 \mathrm{~cm}$ & $\begin{array}{c}\text { Rice-Rice, Rice-Wheat, Maize-Rice, Rice-Vegetable, Rice-Potato, } \\
\text { Maize-Wheat, Maize-Mustard, Maize-Potato }\end{array}$ \\
\hline $\begin{array}{c}\text { Batase (Cam- } \\
\text { bisol) }\end{array}$ & $1300 \mathrm{~m} \mathrm{(ms)}$ & Warm temperate & $0-20 \mathrm{~cm}$ & $\begin{array}{c}\text { Rice-Wheat, Rice-Potato, Rice-Vegetable, Maize-Wheat, Maize- } \\
\text { Potato }\end{array}$ \\
\hline $\begin{array}{c}\text { Lumle } \\
\text { (Luvisols) }\end{array}$ & $1900 \mathrm{~m} \mathrm{(msl)}$ & Temperate & $0-20 \mathrm{~cm}$ & Rice-Wheat, Maize-Millet, Maize-Barley \\
\hline
\end{tabular}

Table 2: Soil sampling site description.

\section{Soil samples collection and preparation}

Soil samples (arable soils) were collected from the depth of 0 $20 \mathrm{~cm}$ at different locations with the help of auger on the last week of May 09. Each location has been classified into low land (khet) and upland (Bari). The previous crops of khet and Bari of Bhairawa (Fluvisols), Chitwan (Regosols), Batase (Cambisols) and Lumle (Luvisols) were Paddy and Wheat, but in Panchkhal (Cambisols) were Paddy and Maize respectively.

Chemical methods

Soil pH (1:2.5)

Soil pH was measured by shaking $5 \mathrm{~g}$ of soil $\left(2 \mathrm{~mm}, 24 \mathrm{~h}, 105^{\circ} \mathrm{C}\right)$ with $12.5 \mathrm{ml}$ of de--ionized water (triplicate) and $12.5 \mathrm{ml}$ of $0.01 \mathrm{M}$ $\mathrm{CaCl}_{2}$ solution (triplicate). This was permitted to stand for one hour and the pH was measured with a glass calomel electrode [4].

Soil total carbon $\left(\mathrm{C}_{\text {tot }}\right)$ and nitrogen $\left(\mathrm{N}_{\text {tot }}\right)$

Soil $\mathrm{C}_{\text {tot }}$ and $\mathrm{N}_{\text {tot }}$ were measured in $0.5 \mathrm{mg}$ of fine soil powder by combustion using a Fissions Instruments NA1500 NCS analyser [5].

\section{Soil $\mathrm{KCl}$ extractable $\mathrm{NH}_{4}{ }^{+}-\mathrm{N}$ and $\mathrm{NO}_{3}-\mathrm{N}$}

Plant available $\mathrm{N}\left(\mathrm{KCl}\right.$ extractable $\mathrm{NH}_{4}{ }^{+}-\mathrm{N}$ and $\left.\mathrm{NO}_{3}{ }^{-} \mathrm{N}\right)$ was measured according to methods described by Blakemore., et al. [5] by shaking $5 \mathrm{~g}$ of field moist sample with $25 \mathrm{ml}$ of $2 \mathrm{M} \mathrm{KCl}$ solution for 2 hours. After extraction, all samples were filtered through a Whatman no 42 filter paper and leachates were analysed for NH4+-N and $\mathrm{NO}_{3}{ }^{--\mathrm{N}}$ in a flow injection analyser (FIA star 5010 analyser).

\section{Soil cation exchange capacity (CEC)}

The CEC was measured by displacing exchangeable base cations ( $\mathrm{Ca}, \mathrm{Mg}, \mathrm{K}$ and $\mathrm{Na}$ ) from soil particle exchange sites by leaching triplicate samples $(10 \mathrm{~g})$ of each soil with $125 \mathrm{ml}$ of $0.01 \mathrm{M}$ ammonium acetate solution ( $\mathrm{pH} 7$ ). The base cations were analysed by atomic absorption spectrometry (AAS) with air acetylene flame (Perkin Elmer A Analyst100). The soil was then washed several times with $80 \%$ ethanol to rinse excess $\mathrm{NH}_{4}^{+}$from soil particles surfaces and leached again with $125 \mathrm{ml}$ of $0.01 \mathrm{M}$ Nacl. Ammonium displaced by $\mathrm{Na}$ was then analysed by flow injection analysis with a FIA star 5010 analyser for the estimation of CEC [5].

\section{Physical Methods}

Soil moisture content

Soil moisture content (\%) was measured by drying the $1 \mathrm{~g}$ of soil at $105^{\circ} \mathrm{C}$ until the dry weight was constant by using MB 45 moisture analyser.

\section{Particle size analysis (PSA)}

Particle size analysis was done by sedimentation analysis (hydrometer method) by weighted 50g of air--dry soil with addition of calgon reagent and about $400 \mathrm{ml}$-distilled water in a beaker. The suspension was thoroughly stirred. Then transferred to the one litre glass cylinder and made volume with distilled water up to the mark. The suspension was mixed well and placed the thermometer and the hydrometer slowly so as not to disturb soil suspension and took thermometer and hydrometer reading in 40 seconds (silt and clay $\%)$. Then the jar was left for two hours for the complete settlement of silt particles. Recorded the hydrometer and thermometer reading after two hours without disturbance of suspension (clay \%) [6].

\section{Soil water holding capacity (WHC)}

The soil WHC was measured according to Page., et al [19]. The soils were adjusted to 50 and $60 \%$ of their WHC by placing moist soils with known moisture content in the container on the scale. Deionised water was then added drop wise to the soil until the total weight corresponded to soil maintained at 50 to $60 \%$ of its WHC. 
Biological methods

Soil microbial biomass Carbon ( mic $_{\mathrm{c}}$ )

Total soil microbial biomass carbon (micc) was determined by the chloroform fumigation method [35]. Soils were adjusted to 50 - 60\% water holding capacity (WHC) to ensure optimum conditions for microbial activities [7]. The sample was left for 3 days to equilibrate, then $5 \mathrm{~g}$ of field moist soil was weighed and added to a glass Universal bottles. One replicate for each soil and procedural blank were taken for both fumigated and non-- fumigated samples. Fumigated samples were placed in desiccators with moist tissue paper and a $50 \mathrm{ml}$ glass beaker containing $25 \mathrm{ml}$ acid--washed chloroform and anti--bumping granules. Non-fumigated samples were extracted at the same time as fumigation was occurring with $25 \mathrm{ml}$ of $\mathrm{K}_{2} \mathrm{SO}_{4}$ $(0.5 \mathrm{M})$ for 30 minutes. Fumigated samples were also extracted with $25 \mathrm{ml}$ of $\mathrm{K}_{2} \mathrm{SO}_{4}(0.5 \mathrm{M})$ for 30 minutes after the $24 \mathrm{~h}$ fumigation period. Dissolved organic carbon (DOC) was analysed in fumigated and non--fumigated samples in an aqueous carbon analyser (LABTOC Pollution and Process Monitoring) with UV digestion and infrared detector. The KEC factor used was

0.33 for mineral soils [27] and 0.25 for organic soils [35].

\section{Soil dehydrogenase activity (DH)}

Initially, soils were adjusted to $50--60 \%$ WHC and left to equilibrate for 3 days prior to assay [7]. Dehydrogenase activity was determined by a modified method of Trevors [32] by adding $1 \mathrm{~g}$ of field moist soil into sterile universal bottles. Ten $\mathrm{ml}$ of sterile substrate solution $(0.1 \%(\mathrm{w} / \mathrm{v}) \mathrm{p}$-- iodonitetrazolium chloride (INT) (within the buffer $0.5 \mathrm{M} \mathrm{N}$-tris (hydroxymethyl) methyl 1 - 2 aminoethane-sulfonic acid (TES), adjusted to pH 7.8 with $5 \mathrm{M} \mathrm{NaOH}$ ) and placed on an end--over shaker for $24 \mathrm{~h}$. After shaking incubation, $10 \mathrm{ml}$ of ethanol was added to the samples to inhibit enzyme activity [27] and samples were there after placed into $50 \mathrm{ml}$ plastic centrifuge tubes. Samples were centrifuged (Coolspin 2 MSE, UK) for 20 minutes at $1500 \mathrm{~g}$ and $4^{\circ} \mathrm{C}$. Samples were subsequently transferred to luminom eter cuvettes and absorbance was measured at $490 \mathrm{~nm}$ on linear spectrometer (Cecil Instruments CE373). Standard curves were determined using iodonitetrazolium formazan (INTF) and activity was expressed as $\mu \mathrm{g} g-1 \mathrm{~d}^{-1}$ of dry soil.

\section{Soil phosphatase activity (PHOS)}

Phosphatase activity was measured according to the method described by Tabatatai and Bremner [29]. One gram of field moist soil was placed in a glass test tube, to which $4 \mathrm{ml}$ of de--ionized water, $0.25 \mathrm{ml}$ toluene and $1 \mathrm{ml} 0.015 \mathrm{M} \mathrm{p}$--nitrophenyl phosphate (sub- strate) was added. A marble was placed on the top of the test tube and tubes were incubated at $37^{\circ} \mathrm{C}$ for $1 \mathrm{~h}$. Procedural blanks without soil additions were made. After incubation, $1 \mathrm{ml} 0.5 \mathrm{M} \mathrm{CaCl}_{2}$ (to determine the reaction) and $4 \mathrm{ml}$ of $0.5 \mathrm{M} \mathrm{NaOH}$ extractant were added, and rubber bungs placed on tubes. Tubes were shaken for 30s and filtered (Whatman No1). Absorbance was determined by spectrophotometry at $400 \mathrm{~nm}$, which express in $\mu \mathrm{g} \mathrm{g}^{-1} \mathrm{~h}^{-1}$ of soil. Standards (p--nitrophenol) were used to determine sample concentrations.

\section{Soil ATP}

Soil ATP was measured according to Tsai., et al [33]. One g of dry weight soils was shaken with $10 \mathrm{ml}$ of cold $\left(0^{\circ} \mathrm{C}\right)$ extractant (500 $\mathrm{mM} \mathrm{H}_{2} \mathrm{SO}_{4} \mathrm{mM} \mathrm{Na}_{2} \mathrm{HPO}_{4}$ ) for 15 minutes (150 rev min ${ }^{-1}$ ). To allow for correction of ATP recovery, a calibration graph was produced using a standard addition method. One g of soil was added to tubes containing $9.5 \mathrm{ml}$ of the cold sulfuric acid--phosphate extractant and $0.5 \mathrm{ml}$ of ATP (Sigma Chemicals). Blanks were generated by autoclaving soil extracts. Soil suspensions (samples, blanks and ATP standards) were shaken for $5 \mathrm{~s}$. Fifty $\mu \mathrm{l}$ portions were pipette from the upper part of the suspensions into $1.5 \mathrm{ml}$ portions of $250 \mathrm{mM}$ Tris buffer at pH 7.5, containing 4 mM EDTA (Trizma-7.5, Sigma) and were kept in an ice bath. Soil ATP was measured using a Celsis low decay rate bioluminescence kit. After shaking for 3s, 100 $\mu \mathrm{l}$ of the neutralized extract was pipette into cuvettes containing $100 \mu \mathrm{l}$ of ATP releasing agent. Thereafter cuvettes were placed in a measuring chamber for a further 10 s and then $100 \mu \mathrm{l}$ of bioluminescence reagent was injected. Light emission was measured with spectrophotometer. The ATP content of soil samples read from the standard curve and corrected for recovery of ATP.

\section{Soil respiration}

Basal respiration measurements were conducted according to methods outlined by Dawson., et al. [7] and Paton., et al. [17] by placing $1 \mathrm{~g}$ of field moist soil into $9 \mathrm{ml}$ vial (vacuette) before freezing. Twenty four hours prior to sampling, vials were sealed with an air tight septa cap. Gas samples were obtained with a $250 \mu \mathrm{l}$ syringe through the septa and respired $\mathrm{CO}_{2}$ measured in a gas chromatograph (Chrompack CP 9001) with a $2.0 \mathrm{~m}$ x 1/8" x $2.0 \mathrm{~mm}$ column (Poropak QS) and $\mathrm{N}_{2}$ carrier gas $\left(20 \mathrm{ml}^{-1} \mathrm{~min}\right.$ ). Gas standards from Linde gases, Aberdeen were used for calibration.

\section{Potential nitrification rate (PNR)}

The PNR was determined using the method by Dawson., et al [7]. Initially, soils were adjusted to $50-60 \%$ WHC and left to equilibrate for $3 \mathrm{~d}$. Five $\mathrm{g}$ of each samples were placed into $250 \mathrm{ml}$ conical 
flasks, covered with parafilm and left to equilibrate for further $16 \mathrm{~h}$ at room temperature. Subsequently, a $5 \mathrm{ml}$ solution comprising 2 $\mathrm{mM} \mathrm{NaClo}$ and $2 \mathrm{mM}(\mathrm{NH} 4) 2 \mathrm{SO}_{4}$ was added and the flasks were placed on an orbital shaker incubator, set at $25^{\circ} \mathrm{C}$ and $120 \mathrm{rpm}$ for $4 \mathrm{~h}$. The suspension were than centrifuged (Coolspin 2 MSE, UK) at $1500 \mathrm{~g}$ and $4^{\circ} \mathrm{C}$ for 30 minutes, filtered at $0.45 \mu \mathrm{m}$ and $\mathrm{NH} 4+-\mathrm{N}$ and $\mathrm{NO}_{3}-\mathrm{N}$ concentration of the filtrate measured using a flow injection analyser (TECATOR FIA Star, UK) to determine $\mathrm{NO}_{2}$ - and $\mathrm{NO}_{3}-(\mu \mathrm{mol}$ $\operatorname{kg}-1 \mathrm{~d}^{-1}$ ) in the soil.

\section{Statistical analysis}

Initially, parametric testing was performed. Normality tests were used to determine data set was normally distributed or not. Relationships between data were tested using Pearson's correlation coefficient. Multivariate analyses (PCA) were performed on measured soil chemical and biological parameters to test whether these properties discriminate between RSGs. All analyses were performed at $p$ $\leq 0.05$ using MINITAB (Release 14.20).
Results

Soil characterization

Cambisols collected from Batase $(1300 \mathrm{~m})$ were light brown $(7.5$ YR 5/8) to yellowish red (5 YR 4/6) and Panchkhal (750m) were brown (7.5 YR 5/2) to yellowish red (5 YR 5/8) with silty loam and sandy loam textured soil respectively. Regosols collected from Chitwan $(224 \mathrm{~m})$ were very dark grey (7.5 YR 3/1) to yellowish brown (5 YR 5/8) with sandy loam textured, Fluvisols collected from Bhairawa $(120 \mathrm{~m})$ were brownish yellow (10YR 6/6) to light yellowish brown (10YR 6/4) with silty clay loam textured and Luvisols collected from Lumle $(1900 \mathrm{~m})$ were light yellowish brown (10 YR 6/4) to strong brown (7.5 YR 4/6) with sandy loam textured respectively. The forest types associated to sampling sites were subtropical forest in Bhairawa, Chitwan and Panchkhal, warm temperate forest in Batase and temperate forest in Lumle respectively. Soil factors used to differentiate between soils $\left(\mathrm{C}_{\text {tot, }}, \mathrm{N}_{\text {tot' }} \mathrm{CEC}, \mathrm{pH}\right.$, Base saturation (BS) and silt and clay content) as classified by WRB, varied significantly between soils sampled.

\begin{tabular}{|c|c|c|c|c|c|c|c|}
\hline \multirow[t]{2}{*}{ Soil type } & \multicolumn{2}{|c|}{ Soil pH } & \multirow{2}{*}{$\begin{array}{c}\text { CEC } \\
\left(\mathrm{Cmol}_{\mathrm{c}} \mathrm{kg}^{-1}\right)\end{array}$} & \multirow{2}{*}{$\begin{array}{c}\mathrm{Ca} \\
\left(\mathrm{Cmol}_{\mathrm{c}} \mathrm{kg}^{-1}\right)\end{array}$} & \multirow{2}{*}{$\begin{array}{c}\mathrm{Mg} \\
\left(\mathrm{Cmol}_{\mathrm{c}} \mathrm{kg}^{-1}\right)\end{array}$} & \multirow{2}{*}{$\begin{array}{c}\mathrm{K} \\
\left(\mathrm{Cmol}_{\mathrm{c}} \mathrm{kg}^{-1}\right)\end{array}$} & \multirow{2}{*}{$\begin{array}{c}\mathrm{Na} \\
\left(\mathrm{Cmol}_{\mathrm{c}} \mathrm{kg}^{-1}\right)\end{array}$} \\
\hline & $\mathrm{H}_{2} \mathrm{O}$ & $\mathrm{Cacl}_{2}$ & & & & & \\
\hline Cambisol-khet & $5.70(0.23)$ & $5.79(0.17)$ & $3.05(0.49)$ & $1.05(0.13)$ & $0.36(0.05)$ & $0.29(0.12)$ & $0.44(0.02)$ \\
\hline Cambisol-bari & $5.98(0.29)$ & $6.17(0.24)$ & $3.61(0.35)$ & $0.94(0.05)$ & $0.63(0.05)$ & $0.56(0.11)$ & $0.40(0.06)$ \\
\hline Regosol-khet & $6.83(0.03)$ & $6.93(0.04)$ & $1.42(0.37)$ & $0.26(0.08)$ & $0.47(0.16)$ & $0.46(0.02)$ & $0.37(0.13)$ \\
\hline Regosol-bari & $6.20(0.04)$ & $6.29(0)$ & $3.27(0.98)$ & $1.57(0.47)$ & $0.56(0.02)$ & $0.12(0.04)$ & $0.51(0.03)$ \\
\hline Fluvisol-khet & $6.47(0.01)$ & $6.99(0.02)$ & $5.68(1.02)$ & $2.30(0.25)$ & $0.73(0.01)$ & $0.12(0.02)$ & $0.51(0.02)$ \\
\hline Fluvisol-bari & $6.14(0.38)$ & $6.26(0.39)$ & $4.50(2.66)$ & $2.15(1.50)$ & $0.75(0.02)$ & $0.13(0.01)$ & $0.47(0.22)$ \\
\hline Luvisol-khet & $5.23(0.36)$ & $5.50(0.24)$ & $3.01(0.55)$ & $0.81(0.16)$ & $0.29(0.10)$ & $0.30(0.07)$ & $0.44(0.11)$ \\
\hline Luvisol-bari & $5.89(0.32)$ & $6.19(0.26)$ & $5.97(0.06)$ & $2.45(0.65)$ & $0.54(0.06)$ & $0.72(0.11)$ & $0.28(0.03)$ \\
\hline () - Value of se & & & & & & & \\
\hline
\end{tabular}

Table 3a: Mean values of chemical properties of all soil types. Cambisols ( $\mathrm{n}=24, \mathrm{se}=6.57)$, Regosols ( $n=12$, se=2.17), Fluvisols ( $n=12$, se=2.41), Luvisols ( $n=12, \mathrm{se}=2.63)$.

\begin{tabular}{|l|c|c|c|c|c|}
\hline \multicolumn{1}{|c|}{ Soil type } & $\mathbf{C}_{\text {tot } \%}$ & $\mathbf{N}_{\text {tot } \%}$ & $\mathbf{C : ~} \mathbf{N}$ & $\left.\mathbf{N O}_{\mathbf{3}} \mathbf{( m g ~ k g - 1}\right)$ & $\left.\mathbf{N H}_{\mathbf{4}} \mathbf{( m g ~} \mathbf{~ k g}-\mathbf{1}\right)$ \\
\hline Cambisol-khet & $1.23(0.17)$ & $0.09(0.03)$ & $16.5(2.90)$ & $101.01(44)$ & $116.3(66)$ \\
\hline Cambisol-bari & $0.93(0.25)$ & $0.06(0.02)$ & $15.7(1.77)$ & $43.7(16)$ & $2.55(1.02)$ \\
\hline Regosol-khet & $3.60(0.47)$ & $0.11(0.04)$ & $36.9(7.82)$ & $2.18(1.73)$ & $5.55(0.30)$ \\
\hline Regosol-bari & $1.52(0.09)$ & $0.09(0.01)$ & $17.9(2.06)$ & $32.88(7.73)$ & $2.0(0.25)$ \\
\hline Fluvisol-khet & $0.77(0.05)$ & $0.04(0.03)$ & $41.8(30.0)$ & $34.25(12.7)$ & $1.98(0.13)$ \\
\hline Fluvisol-bari & $0.92(0.10)$ & $0.06(0.01)$ & $16.7(0.30)$ & $24.78(13.78)$ & $2.58(0.03)$ \\
\hline Luvisol-khet & $1.59(0.19)$ & $0.12(0.02)$ & $13.8(0.19)$ & $23.1(3.80)$ & $118.13(43)$ \\
\hline Luvisol-bari & $1.12(0.03)$ & $0.08(0.02)$ & $15.6(3.44)$ & $11.33(7.55)$ & $79.3(9.75)$ \\
\hline O- Value of se & & & & & \\
\hline
\end{tabular}

Table 3b: Mean values of chemical properties of all soil types. Cambisols $(n=24, \mathrm{se}=6.57)$, Regosols ( $n=12$, se=2.17), Fluvisols ( $n=12$, se=2.41), Luvisols ( $n=12, \mathrm{se}=2.63$ ). 


\begin{tabular}{|c|c|c|c|c|c|c|c|}
\hline Soil type & $\begin{array}{c}\text { mic }_{\mathrm{c}} \\
\left(\mathrm{mg} \mathrm{100g}^{-1}\right)\end{array}$ & $\begin{array}{c}\text { DH } \\
\left(\mu \mathrm{g}^{-1} \mathrm{~d}^{-1}\right)\end{array}$ & $\begin{array}{c}\text { Phos } \\
\left(\mu \mathrm{g}^{-1} \mathrm{~h}^{-1}\right)\end{array}$ & $\begin{array}{c}\text { ATP } \\
\left(\mathrm{mg} \mathrm{g}^{-1}\right)\end{array}$ & $\begin{array}{c}\text { Resp } \\
\left(\mathrm{mg} \mathrm{g}^{-1} \mathrm{~d}^{-1}\right)\end{array}$ & $\begin{array}{c}\mathrm{NO}_{3}^{-}-\mathrm{N} \\
\left(\mathrm{mg} \mathrm{kg}^{-1}\right)\end{array}$ & $\begin{array}{c}\mathrm{NO}_{2}^{-}-\mathrm{N} \\
\left(\mathrm{mg} \mathrm{kg}^{-1}\right)\end{array}$ \\
\hline Cambisolkhet & $17.48(3.56)$ & $7.00(0)$ & $42.6(18.23)$ & $0.75(0.03)$ & $0.01(0)$ & $26.63(11.44)$ & 2.17 (1.18) \\
\hline Cambisol-bari & $26.03(7.87)$ & $7.25(0)$ & $158.9(18.06)$ & $0.78(0.07)$ & $0.01(0)$ & $10.66(3.84)$ & $0.56(0.18)$ \\
\hline Regosol-khet & $27.58(11.65)$ & $9.00(0)$ & $66.71(19.95)$ & $0.89(0.04)$ & $0.03(0)$ & $13.25(9.26)$ & $1.78(0.06)$ \\
\hline Regosol-bari & $28.8(2.76)$ & $11.50(0)$ & $69.54(21.93)$ & & & $14.43(3.82)$ & $0.90(0.13)$ \\
\hline Fluvisol-khet & $29.82(3.23)$ & $7.50(0)$ & $13.58(7.76)$ & $0.77(0.02)$ & $0.01(0)$ & $8.84(2.53)$ & $1.09(0.24)$ \\
\hline Fluvisol-bari & $62.2(8.41)$ & $5.00(0)$ & $17.54(5.58)$ & $0.52(0.08)$ & $0.02(0)$ & $9.87(0.88)$ & $1.33(0.10)$ \\
\hline Luvisol-khet & $29.63(7.02)$ & $9.50(0)$ & $33.78(18.9)$ & $0.98(0.13)$ & $0.01(0)$ & $15.43(0.52)$ & $0.26(0.08)$ \\
\hline Luvisol-bari & $21.34(4.98)$ & $4.50(0)$ & $29.69(5.11)$ & $0.54(0.06)$ & $0.01(0)$ & $2.96(1.05)$ & $1.33(1.19)$ \\
\hline
\end{tabular}

\section{(0-- Value of se}

Table 4: Mean values of biological properties of all soil types. Cambisols $(n=24, \mathrm{se}=6.57)$, Regosols ( $n=12$, se=2.17), Fluvisols ( $n=12$, se=2.41), Luvisols $(n=12, \mathrm{se}=2.63$ ).

Soil $\mathrm{C}_{\text {tot }}$ varied across soils with significant difference between all soils. Regosols in both khet and bari had the highest $\mathrm{C}_{\text {tot }}$ content (3.6 and 1.52\%) while Fluvisols had low $\mathrm{C}_{\text {tot }}(0.77$ and $0.92 \%$ respectively). The soil CEC was significantly different between RSGs. CEC of all soil types in upland were found to be higher than lowland but reverse trends were observed in Fluvisols within the same soil type. Fluvisols contained highest CEC $\left(5.09 \mathrm{Cmol}_{\mathrm{c}} \mathrm{kg}^{-1}\right)$ followed by Luvisols (4.49 $\mathrm{Cmol}_{\mathrm{c}} \mathrm{kg}^{-1}$ ), Cambisols ( $3.33 \mathrm{Cmol}_{\mathrm{c}} \mathrm{kg}^{-1}$ ) and Regosols $\left(2.35 \mathrm{Cmol}_{\mathrm{c}} \mathrm{kg}^{-1}\right)$ respectively. $\mathrm{N}_{\text {tot }}$ also measured greater in low land than in upland but in Fluvisol opposite trend was observed. The highest $\mathrm{N}_{\text {tot }}$ was observed in Luvisols and Regosols (0.2\%) but Fluvisols had low $\mathrm{N}_{\text {tot }}(0.1 \%)$. Soil $\mathrm{pH}$ measured with $0.01 \mathrm{M} \mathrm{Cacl}{ }_{2}$ for all soils was higher than $\mathrm{pH}$ measured with $\mathrm{H}_{2} \mathrm{O}$. The highest soil $\mathrm{pH}$ with $\mathrm{H}_{2} \mathrm{O}$ found in Regosols (6.52) and with $\mathrm{Cacl}_{2}$ in Fluvisols (6.99). The lowest $\mathrm{pH}$ was observed in Luvisols with $\mathrm{H}_{2} \mathrm{O}$ (5.23) and with $\mathrm{Cacl}_{2}$ (5.5) respectively. The values of exchangeable cation were found in the order of $\mathrm{Ca}>\mathrm{Mg}>\mathrm{Na}>\mathrm{K}$ in all soil types.

Correlations between soil chemical and biological parameters for each reference soil group (RSG)

Soil $\mathrm{C}_{\text {tot }}$ had strong positive correlation with Soil mic $\mathrm{c}^{\prime}$ DH, ATP and soil respiration. Soil $\mathrm{N}_{\text {tot }}$ correlated positively with ATP. Soil CEC correlated positively with DH and ATP although negative correlation observed with mic ${ }_{c}$. Mg and Ca correlated negatively with ATP and $\mathrm{K}$ correlated negatively with $\mathrm{DH}$. Soil $\mathrm{pH}$ only correlated positively with soil respiration. Clay content also correlate significantly with ATP.

\begin{tabular}{|l|c|c|c|c|c|}
\hline & mic $_{\mathbf{c}}$ & DH & ATP & Phos & Resp \\
\hline $\mathrm{C}_{\text {tot }}$ & 0.029 & $0.317^{*}$ & 0.396 & 0.147 & $0.699^{* * *}$ \\
\hline $\mathrm{N}_{\text {tot }}$ & -0.15 & 0.197 & $0.400^{*}$ & 0.195 & 0.192 \\
\hline $\mathrm{CEC}$ & -0.017 & $-0.548^{* *}$ & $-0.589^{* *}$ & -0.207 & -0.316 \\
\hline $\mathrm{Na}$ & 0.178 & 0.107 & 0.102 & -0.137 & 0.041 \\
\hline $\mathrm{K}$ & 0.415 & $-0.479^{*}$ & -0.381 & 0.035 & -0.407 \\
\hline $\mathrm{Mg}$ & 0.362 & $-0.439^{*}$ & $-0.467^{*}$ & -0.007 & 0.217 \\
\hline $\mathrm{Ca}$ & 0.076 & 0.401 & $-0.401^{*}$ & -0.203 & -0.17 \\
\hline $\mathrm{Clay}$ & 0.264 & -0.396 & $-0.483^{*}$ & -0.365 & 0.085 \\
\hline Silt & 0.252 & -0.199 & -0.138 & $0.476^{*}$ & -0.098 \\
\hline $\mathrm{pH}-\mathrm{H}_{2} \mathrm{O}$ & 0.17 & -0.038 & -0.108 & -0.189 & $0.514^{* *}$ \\
\hline${\mathrm{pH}-\mathrm{Cacl}_{2}}$ & 0.151 & 0.03 & -0.063 & -0.22 & $0.427^{*}$ \\
\hline$<0.0001^{* * *}$ & & & & & \\
\hline$<0.01^{* *}$ & & & & & \\
\hline$<0.05^{*}$ & & & & & \\
\hline
\end{tabular}

Table 5: Pearson's correlation coefficients using all soil types for displaying relationship between soil chemical and biological properties.

DH enzymatic activities were highest in Regoslos $(10.25 \mu \mathrm{g}$ $\left.\mathrm{g}^{-1} \mathrm{~d}^{-1}\right)$ and lowest in Fluvisols $\left(6.25 \mu \mathrm{g} \mathrm{g}^{-1} \mathrm{~d}^{-1}\right)$. Similar trends were found in Cambisols and Luvisols $\left(14 \mu \mathrm{g} \mathrm{g}^{-1} \mathrm{~d}^{-1}\right)$. Soil ATP did not differ significantly between Fluvisols and Luvisols and were lowest among all soils (ATP 0.65 and $0.76 \mathrm{mg} \mathrm{g}^{-1}$ respectively). The highest ATP was measured in Regosols $\left(0.95 \mathrm{mg} \mathrm{g}^{-1}\right)$ followed by 
Cambisols ( $\left.0.77 \mathrm{mg} \mathrm{g}^{-1}\right)$. Highest phosphatase activities were measured in Cambisols (Phos $100.8 \mu \mathrm{g} \mathrm{g}^{-1} \mathrm{~h}^{-1}$ ) than Regosols (68.12 $\mu \mathrm{g}$ $\mathrm{g}^{-1} \mathrm{~h}^{-1}$ ), Luvisols (31.7 $\left.\mu \mathrm{g} \mathrm{g}^{-1} \mathrm{~h}^{-1}\right)$ and Fluvisols (15.56 $\left.\mu \mathrm{g} \mathrm{g}^{-1} \mathrm{~h}^{-1}\right)$ respectively. Mic measured in the low land were higher than upland in all soil except Luvisols that followed reverse trend. Highest mic $_{\mathrm{c}}$ found in Fluvisols (46.01 mg 100g-1) and lowest in Cambisol (21.75 mg $\left.100 \mathrm{~g}^{-1}\right)$. Measured soil respiration was highest in Regosols $\left(0.03 \mathrm{mg} \mathrm{g}^{-1} \mathrm{~d}^{-1}\right)$ and same trend $\left(0.01 \mathrm{mg} \mathrm{g}^{-1} \mathrm{~d}^{-1}\right)$ was followed by remaining soil types. When soil chemical parameters ( $\mathrm{pH}, \mathrm{CEC}$, $\mathrm{C}_{\text {tot' }} \mathrm{Ca}$ ) were correlated against soil biological parameters $\left(\mathrm{mic}_{\mathrm{c}} \mathrm{DH}\right.$ and ATP), soil types formed distinct groups (Figure 1 and 2). This study also showed the significance relationship between soil mic and soil ATP ( $\mathrm{p} \leq 0.05)$ and respiration $(\mathrm{P} \leq 0.0001)$.

Soil ATP was significantly correlated with soil $\mathrm{pH}$ and exchangeable Ca and all RSGs except Luvisols showed the distinct groups (Figure 1a and 1b). Ctot correlated significantly with micc and soil ATP and showed clear grouping in all types of soils (Figure 1c and 1d).
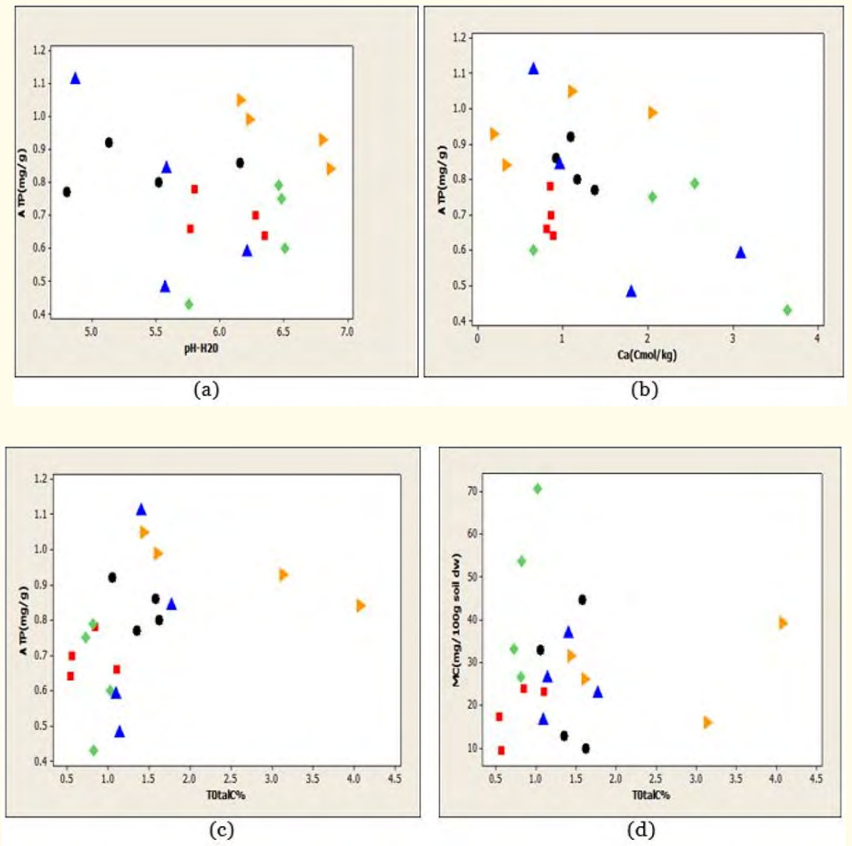

Figure 1: Relationship between a) Soil ATP and pH. b) Soil ATP and exchangeable Ca. c) Soil ATP and Ctot. d) micc and Ctot for all soil reference groups. $\bullet$ Cambisols (Batase), $\mathbf{\square}=$ Cambisols

(Panchkhal), $\diamond=$ Fluvisols, $\bullet=$ Luvisols, $\bullet=$ Regosols .
Soil biological activities like DH and soil ATP significantly correlated with CEC and was highly influenced with Cambisols and Regosols (Figure 2a and 2b).
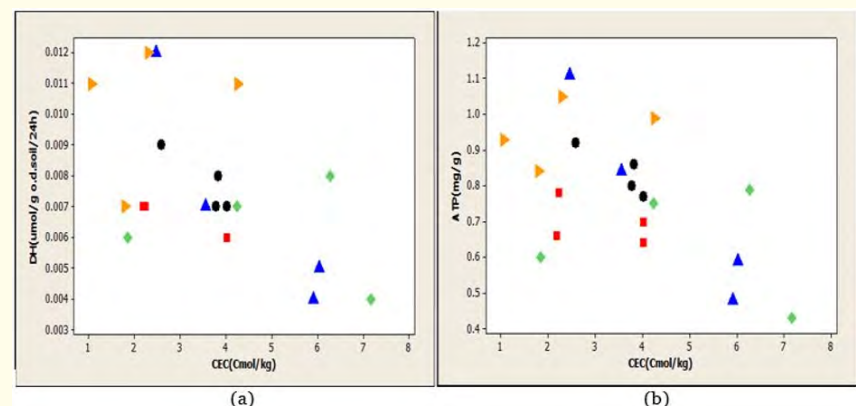

Figure 2: Relationship between a) soil dehydrogenase and CEC b) soil ATP and CEC for all soil reference groups. - = Cambisols (Batase), $\mathbf{\square}=$ Cambisols (Panchkhal), $\diamond=$ Fluvisols, $\bullet=$ Luvisols, $\bullet=$ Regosols

\section{Principal component analysis (PCA)}

PCA using all 20 measured parameters separated RSGs into discrete clusters (Figure 3a). The vector-loading plot (Figure 3b) reflected which measured soil parameters had more influence on grouping and separation of soils. PCA scores that separated Fluvisols were CEC and BS (Ca, Mg, Na and K). Cambisols (Panchkhal) and Lithosols were also influenced by CEC and BS respectively. However, Cambisols (Batase) also influenced by PNR, $\mathrm{N}_{\text {tot' }} \mathrm{C}_{\text {tot }}$ and DH. Regosols were mostly influenced by micc, pH H2O, pH Cacl2 and soil respiration. Luvisols also influenced by Ntot, Ctot and $\mathrm{DH}$ respectively. PCA was repeated either chemical factors ( $\mathrm{pH}, \mathrm{CEC}$, BS, $\mathrm{NO}_{3}, \mathrm{NH}_{4}, \mathrm{C}_{\text {tot }}$ and $\mathrm{N}_{\text {tot }}$ ) or biological factors (DH, micc, ATP, Phos, Resp and PNR) for suitable characterisation of RSGs.

The influenced of the biological parameters such as DH, soil ATP and Phos was observed in Rigosols but Micc and soil Respiration highly influence Cambisol (Panchkhal) and Fluvisols. However, PNR, ATP and phosphatase activities were observed in Cambisols (Batase). Luvisols was not found in clear cluster and mixed influenced was observed as DH, phso, resp, and micc (Figure 4a and4 b). 


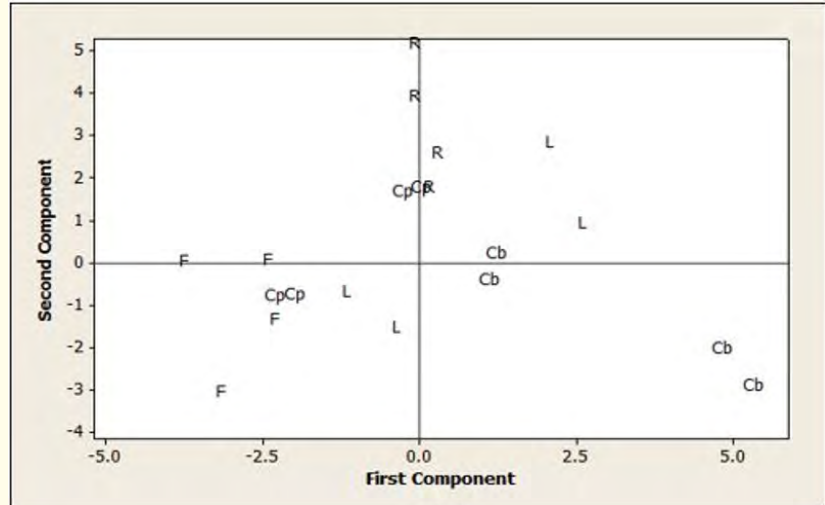

(a) |

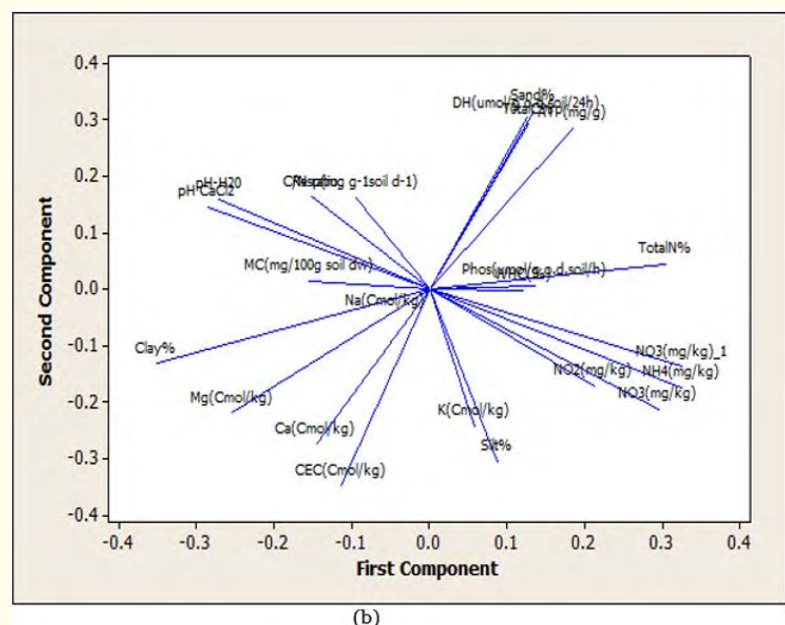

(b)

Figure 3: (a) Principal component analysis plot showing grouping of soil taxonomic groups. The plot included all measured chemical and biological properties. (b) Vector diagram displaying how measured properties influence separation soil taxonomic groups. $\mathrm{Cb}=$ Cambisols(Batase), $\mathrm{Cp}=$ Cambisols(Panchkhal), R=Regosols, F= Fluvisols, L= Luvisols.

When chemical parameters were used, RSGs were separated well (Figure 5a). Chemical factors contributing to the separation of soils were $\mathrm{pH}$ and $\mathrm{C}_{\text {tot }}$ for Regosols and $\mathrm{pH}, \mathrm{CEC}$ and $\mathrm{BS}$ for Fluvisols. Soil Ntot, $\mathrm{NO}_{3}^{-}-\mathrm{N}, \mathrm{NH}_{4}^{-}-\mathrm{N}$ and exchangeable bases influences the Luvisols. Ctot, CEC, BS separated Cambisol (Panchkhal) and soil exchangeable $\mathrm{K}, \mathrm{CEC}, \mathrm{N}_{\text {tot }}$ and $\mathrm{NH}_{4}$ highly influenced the Cambisols (Batase) (Figure 5a and 5b).

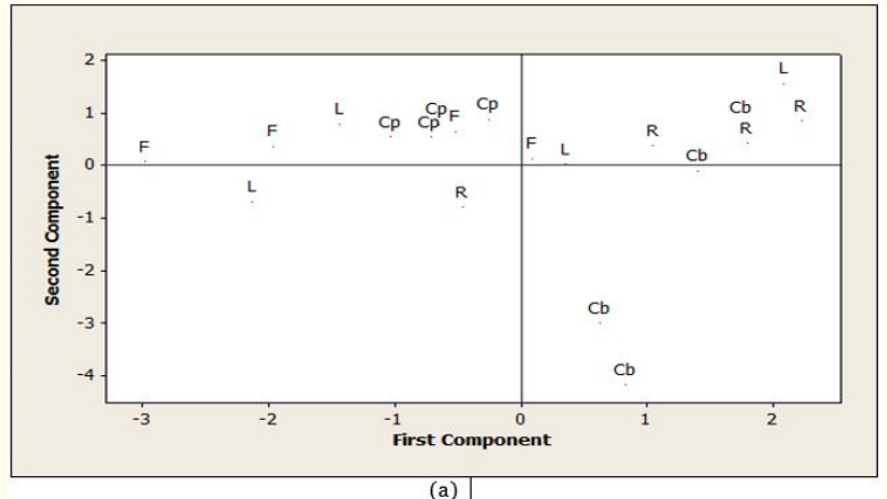

(a)

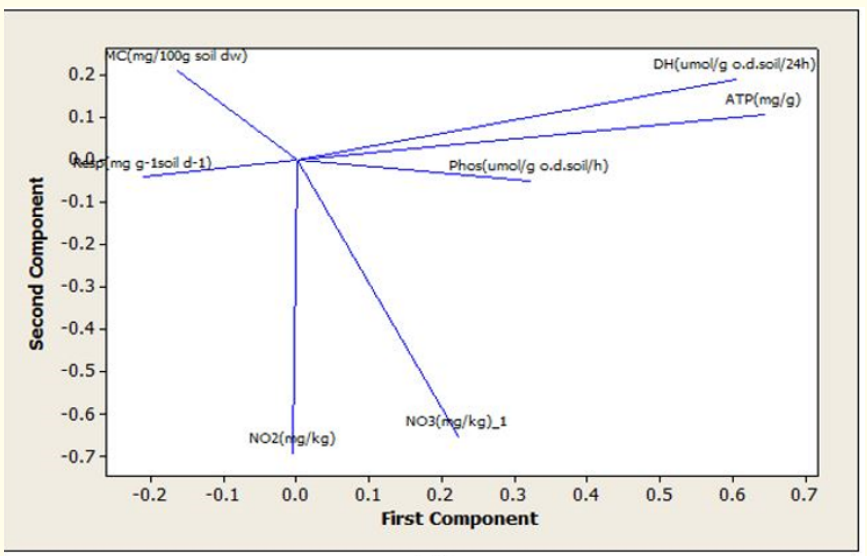

(b)

Figure 4: (a) Principal component analysis plot showing grouping of soil taxonomic groups. The plot included all measured biological properties. (b) Vector diagram displaying how measured properties influence separation soil taxonomic groups. $\mathrm{Cb}=$ Cambisols (Batase), $\mathrm{Cp}=$ Cambisols (Panchkhal), $\mathrm{R}=$ Regosols, $\mathrm{F}=$ Fluvisols, $\mathrm{L}=$ Luvisols.

\section{Discussion and Conclusion}

\section{Soil characterisation}

Individual RSGs (Cambisols, Regosols, Fluvisols and Luvisols) have distinguishing characteristics associated with soil horizons [10]. Soil types influenced microbial biomass carbon and vice versa. The soil types showed homogenous variation in soil basal respiration. Cambisols had lower micc than Eutric vertisol [31]. Similar trends also observed in this study where the micc was lower (21.7) than the Fluvisols (46.01), Regosols (28.2) and Lithosols (25.5). 


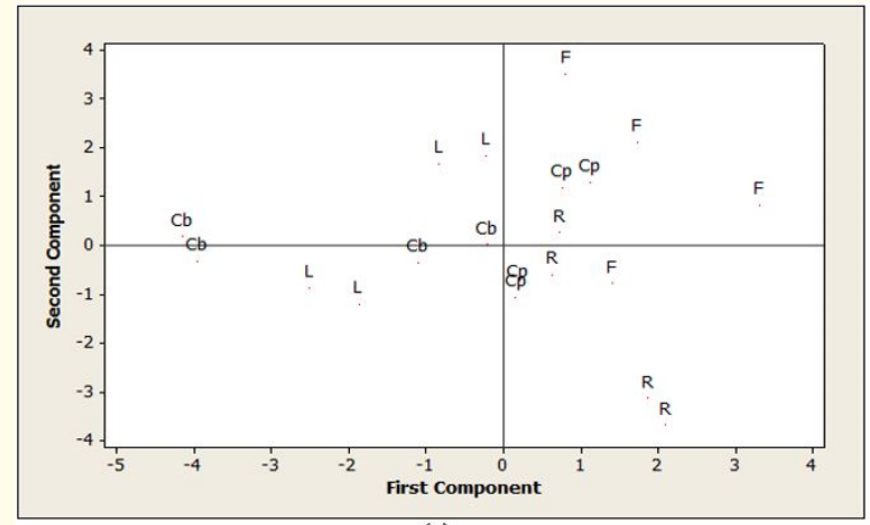

(a)

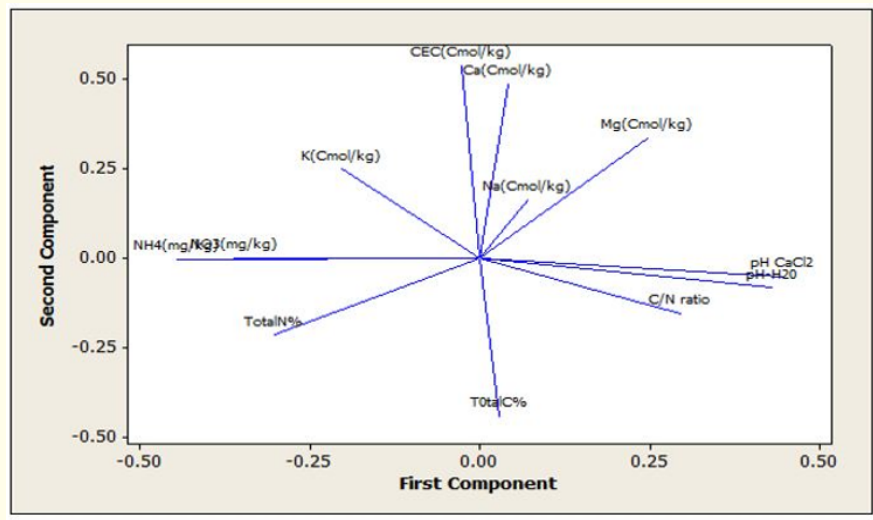

(b)

Figure 5: (a) Principal component analysis plot showing grouping of soil taxonomic groups. The plot included all measured chemical properties. (b) Vector diagram displaying how measured properties influence separation soil taxonomic groups. $\mathrm{Cb}=$ Cambisols (Batase), $\mathrm{Cp}=$ Cambisols(Panchkhal), $\mathrm{R}=$ Regosols, $\mathrm{F}=$ Fluvisols, $\mathrm{L}=$ Luvisols.

Powlsen., et al. [21] reported that microbial biomass, soil basal respiration, enzymatic activities like ATP directly affected by change in soil organic matter. Similar trends were observed in this study. Microbial activities are limited in order by available N, carbon and phosphorus [30].

Researchers [23] reported that soil clay content was the major determining factor for distinctiveness of organic matter, $\mathrm{pH}$ values and microbial characteristics. Soil texture, and structure, WHC, air and heat dynamics affected directly to microbial activities, enzymatic activities and micc of the soil [23]. Saggar., et al. [23] suggest- ed that strong positive correlation between clay content and micc, in this study clay content was showed the positive correlation with enzymatic activities however micc did not show the significant correlation with clay content.

Soil CEC differed significantly in all RSGs. Highest CEC was associated with Fluvisols ( $4.88 \mathrm{Cmol}_{\mathrm{c}} \mathrm{kg}^{-1}$ ) followed by Lithosols (4.5 $\mathrm{Cmol}_{\mathrm{c}} \mathrm{kg}^{-1}$ ), Cambisols ( $\left.3.3 \mathrm{Cmol}_{\mathrm{c}} \mathrm{kg}^{-1}\right)$ and Regosols $\left(2.3 \mathrm{Cmol}_{\mathrm{c}} \mathrm{kg}^{-1}\right.$ ) respectively. Similar trends also followed by exchangeable bases ( $\mathrm{Ca}, \mathrm{Mg}$, and $\mathrm{K})$. Highest $\mathrm{Ca}\left(2.2 \mathrm{Cmol}_{\mathrm{c}} \mathrm{kg}^{-1}\right)$ and $\mathrm{Mg}\left(0.74 \mathrm{Cmol}_{\mathrm{c}} \mathrm{kg}^{-1}\right)$ found in Fluvisols and lowest $\mathrm{Ca}\left(0.99 \mathrm{Cmol} \mathrm{kg}_{\mathrm{c}}^{-1}\right)$ found in Cambisols. Exchangeable K observed highest in Lvuisols $\left(0.51 \mathrm{Cmol}_{\mathrm{c}} \mathrm{kg}^{-1}\right)$ and lowest in Fluvisols $\left(0.12 \mathrm{Cmol}_{\mathrm{c}} \mathrm{kg}^{-1}\right)$. The CEC values in this study were found to be lower than that of many previous studies due to the modified concentration of ammonium acetate (extractent). There had been low concentration of organic matter with mean values of $1.08 \% \mathrm{C}_{\text {tot }}$ and low Ca concentration $(0.99 \mathrm{Cmol}-$ $\left.{ }_{c} \mathrm{~kg}^{-1}\right)$ in this study. Various parameters such as $\mathrm{pH}, \mathrm{CEC}, \mathrm{BS}(\mathrm{Ca}$ $\mathrm{Mg}$, and $\mathrm{K}$ ) measured in Cambisols of this study were comparable with values obtained from a set of dystric Cambisols sampled from New Zealand (Eger and Hewitt, 2008). Low pH values (5.5) in Luvisols indicated low BS, which was comparable to result published by IUSS [10] in an Umbric podzol. Regosols had pH (6.5), which is suitable for Paddy and Wheat cultivation in the context of $\mathrm{Ne}$ pal (Productive soil). Fluvisols had high clay (33\%), Silt (48\%) and sand $(19 \%)$ and CEC also found to be higher $\left(4.9 \mathrm{Cmol} \mathrm{kg}_{\mathrm{c}}{ }^{-1}\right)$ and $\mathrm{pH}$ (6.3).

Correlation between chemical and biological properties for each reference soil group (RSG)

Microbial properties were related to RSGs. This was noticeable when mic c $^{\prime}$ ATP, DH, phos and PNR correlated with criterions given in WRB to classify soils $\left(\mathrm{C}_{\text {tot' }^{\prime}} \mathrm{N}_{\text {tot' }}\right.$ CEC, $\mathrm{pH}$ BS and clay content (Table 5). Soil $C_{\text {tot }}$ correlated significantly with mic $c_{c}$ DH, soil ATP and soil respiration in this study (Table 5). Kizilkaya., et al. [11] has been documented to give significant positive correlation with mic and soil DH in a study. Kizikaya., et al. [11] assigned this to major three components. (i) The microorganisms' ability to degrade compounds (ii) To organic matter degradability to soil and (iii) To high stress conditions due to low $\mathrm{C}_{\text {tot }}$. This was further reinforced with negative correlation observed between $\mathrm{N}_{\text {tot }}$ and mic $_{\mathrm{c}}$ and positively correlated with soil ATP and respiration (Table 5). Li and Chen (2004) when introducing the biological status of agricultural soils came in similar conclusion that they observed the positive correlation between $\mathrm{N}_{\text {tot }}$ and $\mathrm{C}_{\text {tot }}$ and respiration in their findings. 
Chemical parameters such as $\mathrm{pH}$ and CEC influence the soil respiration, mic $\mathrm{c}_{\mathrm{c}}$ and activities of soil enzymes [16]. In this study CEC positively correlated with DH, ATP (Table 5). The positive correlation between soil $\mathrm{pH}\left(\mathrm{H}_{2} \mathrm{O}\right)$, soil $\mathrm{pH}\left(\mathrm{Cacl}_{2}\right)$ and respiration was observed in this study (Table 5). Nutrient availability as well as many other enzymatic activities is influenced by soil $\mathrm{pH}$. Turton., et al. [34] pointed out that the major nutrient ( $\mathrm{N}, \mathrm{P}$ and $\mathrm{K}$ ), bases (Ca and $\mathrm{Mg}$ ) as well as CEC were found low in acidic soils of Nepal. Some workers [16,36] pointed out that chemical and biological properties are suppressed under acid conditions. Xu., et al. [37] pointed out various soil properties associated with different soil types and significant effect on both mic ${ }_{\mathrm{c}}$ and $\mathrm{qCO}_{2}$.

Steenwerth., et al. [28] had aided the importance of soil physical and chemical characteristics, soil resources and soil microbial communities in his study for the utilization of soil classification. Xu., et al. [37] and Ananyeva., et al. [2] documented the difference between metabolic quotients and RSGs. Fluvisols have high CEC and enzymatic activities also recorded low that was similar trends reported by Askin and Kizilkaya [11]. DH was greater in grass land soils compared to agriculture soils indicated that disturbance through ploughing may reduced activities [1]. Mature soils have definitely high micc and temperature influenced higher in phosphatase activities than DH [29].

The use of both chemical and biological characteristics for soil grouping according to their RSGs as reported here was reliable with much previous research. Shipper and Sparling [24] studied various soil parameters including microbial measurements in different land uses and soil types. When conducting PCA both using biological parameters $\left(\mathrm{mic}_{\mathrm{c}^{\prime}}\right.$ microbial respiration, potentially mineralizable $\mathrm{N}$, respiratory quotient and microbial quotient) and chemical parameters ( $\mathrm{C}_{\text {tot' }}, \mathrm{N}_{\text {tot' }} \mathrm{pH}, \mathrm{CEC}$, BS and Olsen $\left.\mathrm{P}\right)$ and reported clear grouping between land uses and soil types. Previous workers [12,36] conducted various researches of effects of soil types on microbial properties. Relationship between bacterial diversity and soil classification in Antartic soils were recently introduced by Aislabie., et al. [1] and used multivariate analysis (PCA) that composition of communities varied with different soil properties. Similar methods were also applied by Ananyeva., et al. [2] to survey micc and microbial respiration in different RSGs (Luvisols, Chernozems, Cryosols, Kastanozems and Glossisols) with PCA stemming clear separation soils. Similarly, microbial respiration and micc were observed as a key factor for the separation of RSGs into discrete cluster in this study.
Main factors used in PCA were similar to the ones used in this study and included soil chemical properties $\left(\mathrm{pH}-\mathrm{H}_{2} \mathrm{O}, \mathrm{pH}-\mathrm{Cacl}_{2}\right.$ $\mathrm{C}_{\text {tot }}, \mathrm{N}_{\text {tot' }} \mathrm{C}: \mathrm{N}, \mathrm{CEC}, \mathrm{Ca}, \mathrm{Mg}, \mathrm{K}, \mathrm{Na}, \mathrm{NO}_{3}-\mathrm{N}$ and $\mathrm{NH}_{4}-\mathrm{N}$ ) and biological properties (micc, DH, Phosphatase, Soil ATP, Respiration, PNR). The current study gave corresponding to these previous finding where the correlation and PCA were used for grouping of soil types. The significance of biomass in any pedogenic explanatory model was highlighted by Minasny., et al [15].

In conclusion, the relationship between biological and chemical parameters in this study found to be clear with sound discrimination. The soil biological parameters such as micc, DH, soil ATP, soil respiration and phosphatase etc. complimented physiochemical attributes used to characterize soils within WRB system. Furthermore, soil biology is a major contributor to soil resilience.

\section{Acknowledgement}

The author is highly grateful Dr. Y.G. Khadka, Chief of Soil Science Division, and NARC, NEPAL for collecting and sending soil samples to the University of Aberdeen for this study. We would like to thanks Norma, Elizabeth Evelyn, Norman, Ken, Jenny, Dev and David Hay for their co-operation in various laboratory work.

I would like to extend my gratitude to my supervisor Dr. Graeme I. Paton, University of Aberdeen; whose immense contribution to this research is no small measure has been of use to me. Without his endless ideas and interest in Nepalese soil fundamental science, this project would not have been made possible.

My thanks go to my wife Renuka Dhakal who has been my backbone since I started this programme, who showed much love and encouragement. I would also like to acknowledge my lovely daughters Vidhata and Bivisha whom I missed too from beginning of my study and finally to my patent Mr. Gehenath Uprety and Mrs. Kamala Devi Uprety for their love and financial support to my study (MSc in Soil Science) in The University of Aberdeen, Scotland, UK.

\section{Bibliography}

1. Aislabie JM., et al. "Relation between soil classification and bacterial diversity in soils of the Ross sea region, Antarctica". Geoderma 144 (2008): 9-20.

2. Ananyeva., et al. "Microbial respiration activities of soils from different climatic regions of European Russia". European Journal of Soil Biology 44 (2008): 147-157. 
3. Bhandari., et al. "Yield and soil nutrient changes in a long-term rice-wheat rotation in India". Soil Science Society of America Journal 66 (2002): 162-170.

4. Black CA. "Methods of Soil Analysis Part ll". American Society of Agronomy Monograph (1965).

5. Blakemore LC., et al. "Methods of chemical analysis of soils". New Zealand Soil Bureau Science Report 80 (1987): 103.

6. Day PR. "Particle Fractionation and Particle Size Analysis. In: C.A. Black (ed). Methods of Soil Analysis Part ll". American Society of Agronomy 9 (1965): 545-567.

7. Dawson., et al. "Application of biological indicators to assess recovery of hydrocarbon impacted soils". Soil Biology Biochemistry 39 (2007): 164-177.

8. Eger A and Hewitt A. "Soils and their relationship to aspect and vegetation history in the eastern southern Alps, Canterbury high country, South Island, New Zealand". Catena 75 (2008): 297-307.

9. Gami SK., et al. "Long term changes in yield and soil fertility in a twenty -year rice-wheat experiment in Nepal". Biology and Fertility of Soils 34 (2001): 73-78.

10. IUSS Working Group WRB, World Reference Base for Soil Resources. 103 (2006).

11. Kizilkaya, R., et al. "Microbiological characteristics of soils contaminated with heavy metals". European Journal of Soil Biology 40 (2004): 95-102.

12. Korkanc SY., et al. "Impacts of land use conversion on soil properties and soil erodibility". Journal of Environmental Biology 29 (2008): 363-370.

13. Ladd JN., et al. "Distribution of organic C-14 and N-15 in particle-size fractions of soils incubated with C-14, N-15-labelled glucose/NH4, and legume and wheat straw residues". Soil Biology and Biochemistry 28 (1996): 893-905.

14. Li XZ and Chen ZZ. "Soil microbial biomass $\mathrm{C}$ and $\mathrm{N}$ along a climatic transect in the Mongolian steppe". Biology and Fertility of Soils 39 (2004): 344-351.

15. Minasny B., et al. "Quantitative models for pedogenesis - A review”. Geoderma 144 (2008): 140-157.

16. Pal R., et al. "Relationship between acidity and microbiological properties in some tea soils". Biology and Fertility of Soils 44 (2007): 399-404.
17. Paton., et al. "An ecotoxicity assessment of contaminated forest soils from the Kola Peninsula". Science of the Total Environment 355 (2006): 106- 117.

18. Paudyal KR., et al. "Maize in Nepal: Production Systems, Constraints, and Priorities for Research. Kathmandu (2001).

19. Page AL., et al. "Methods of Soil Analysis. Part 2: Chemical and Microbiological Properties. Wisconsin: American Society of Agronomy, Soil Science Society of America (ASA - SSSA) 937970.

20. Paz-Gonzalez., et al. "The effect of cultivation on the spatial variability of selected properties of an umbric horizon". Geoderma 97 (2000): 273-292.

21. Powlsen DS., et al. "Measurement in soil microbial biomass provides an early indication of changes in the total organic matter due to Straw Corporation". Soil Biology and Biochemistry 19 (1987): 159-164.

22. Regmi AP., et al. "Yields and soil fertility trends in 20 years Rice-Rice-Wheat experiment". Better Crops International 17 (2003).

23. Saggar S., et al. "Carbon turnover in a range of allophanic soils amended with C-14-labeled glucose". Soil Biology and Biochemistry 26 (1994): 1263-1271.

24. Schipper LA and Sparling GP. "Performance of soil condition indicators across taxonomic groups and land uses". Soil Science Society of America Journal 64 (2000): 300-311.

25. Sherchan DP and Gurung GB. "Effect of five years continuous application of organic and inorganic fertilizers on crop yields and physio-chemical properties of soil under rain fed maize/ millet cropping pattern. PAC Technical Paper No. 168. Pakhribas Agricultural Centre, Dhankuta district, Koshi zone, Nepal (1996).

26. Soil Survey Staff. "Natural Resources Conservation Service, United States Department of Agriculture, Official soil series descriptions (2009).

27. Sparling., et al. "A direct extraction method to estimate soil microbial - C -calibration insitu using microbial respiration and C-14 labelled cells". Soil Biology and Biochemistry 20 (1998): 337-343.

28. Steenwerth KL., et al. "Soil morphology, depth and grapevine root frequency influence microbial communities in a pinot noir vineyard". Soil Biology and Biochemistry 40 (2008): 13301340 . 
29. Tabatabai MA and Bremner JM. "The use of p-nitrophenyl phosphate for assay of soil phosphatase activity". Soil Biology and Biochemistry 1 (1969): 301-307.

30. Teklay, T., et al. "Soil respiration characteristics of tropical soils from agricultural and forestry land-uses at Wondo Genet (Ethiopia) in response to C, N and P amendments". Soil Biology and Biochemistry 36 (2005): 777-786.

31. Trave S., et al. "Carnon and Nitrogen enhancement in Cambisols and Verticals by Acacia spp. In eastern Burkinia Faso: relation to soil respiration and microbial biomass". Applied Soil Ecology 35 (2007): 660-669.

32. Trevors JT. "Dehydrogenase activity in soil: a comparison between the INT and TTC assay". Soil Biology and Biochemistry 16 (1984): 673-674

33. Tsai., et al. "Dynamic Response of Microbial Biomass, Respiration Rate and ATP to Glucose Additions". Soil Biology and Biochemistry 29 (1997): 1249-1256.

34. Turton., et al. "Towards sustainable soil fertility management in the hills of Nepal. Lumle Agricultural Research Center, Nepal/Natural Resources Institute, Chatham Maritime, UK (1995)

35. Vance., et al. "An extraction method for measuring soil microbial biomass in a soil". Plant and Soil 76 (1987): 257-274.

36. Walse C., et al. "Response of six European forest sites to decided and proposed air pollutant emission reductions". Environmental Pollution 98 (1997): 253-267.

37. Xu X., et al. "Influence of vegetation types and soil properties on microbial biomass carbon and metabolic quotients in temperate volcanic and tropical forest soils". Soil Science and Plant Nutrition 53 (2007) 430-440.

Volume 2 Issue 12 December 2018

(C) All rights are reserved by Rajendra Prasad Uprety and Graeme I Paton. 